\title{
"Management of the economic potential of territories in the context of sustainable development: case of Ukraine"
}

Svitlana V. Onyshchuk (D https://orcid.org/0000-0002-4072-6565

AUTHORS

Zoriana Buryk (D https://orcid.org/0000-0002-4394-6766

Pavlo V. Knysh (D https://orcid.org/0000-0002-5854-3820

Svitlana V. Onyshchuk, Zoriana Buryk and Pavlo V. Knysh (2019). Management ARTICLE INFO of the economic potential of territories in the context of sustainable development: case of Ukraine. Problems and Perspectives in Management, 17(4), 13-25. doi:10.21511/ppm.17(4).2019.02

DOI http://dx.doi.org/10.21511/ppm.17(4).2019.02

RELEASED ON Monday, 21 October 2019

RECEIVED ON Monday, 03 June 2019

ACCEPTED ON

Friday, 04 October 2019

\section{(co) EY}

LICENSE

This work is licensed under a Creative Commons Attribution 4.0 International License

JOURNAL

"Problems and Perspectives in Management"

ISSN PRINT $1727-7051$

ISSN ONLINE $1810-5467$

PUBLISHER

LLC "Consulting Publishing Company "Business Perspectives"

FOUNDER

LLC "Consulting Publishing Company "Business Perspectives"

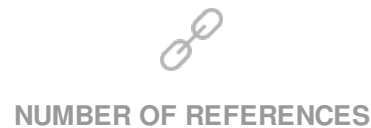

28
NUMBER OF FIGURES

4
琵

NUMBER OF TABLES

4

(C) The author(s) 2021. This publication is an open access article. 


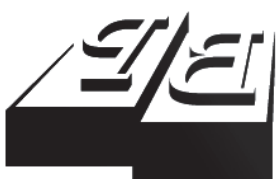

BUSINESS PERSPECTIVES

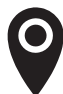

LLC "CPC "Business Perspectives" Hryhorii Skovoroda lane, 10, Sumy, 40022, Ukraine

www.businessperspectives.org

Received on: $3^{\text {rd }}$ of June, 2019 Accepted on: $4^{\text {th }}$ of October, 2019

(c) Svitlana V. Onyshchuk, Zoriana M. Buryk, Pavlo V. Knysh, 2019

Svitlana V. Onyshchuk, Doctor of Science in Public Administration, Associate Professor, Honored Lawyer of Ukraine, Deputy Chairman, Ivano-Frankivsk Regional State Administration, Ivano-Frankivsk, Ukraine.

Zoriana M. Buryk, Doctor of Science in Public Administration, Professor, Department of Management and Business Administration, Institute of Graduate Studies and Preuniversity Education, Vasyl Stefanyk Precarpathian National University, Lviv, Ukraine.

Pavlo V. Knysh, PhD in Public Administration, Deputy Chairman of Zabolotovsky United Territorial Community, Ivano-Frankivsk, Ukraine.

\section{(ㄷ)(ㄱ)}

This is an Open Access article, distributed under the terms of the Creative Commons Attribution 4.0 International license, which permits unrestricted re-use, distribution, and reproduction in any medium, provided the original work is properly cited.

\section{MANAGEMENT OF THE ECONOMIC POTENTIAL OF TERRITORIES IN THE CONTEXT OF SUSTAINABLE DEVELOPMENT: CASE OF UKRAINE}

\begin{abstract}
The process of assessment of economic potential of territories and its governance is a complex task in emerging markets countries, such as Ukraine. This requires the creation of an effective evaluation system and management mechanisms. The paper aims to develop the assessment system of the economic potential of the territories under the conditions of sustainable development and the main components of its management. Methods of research are as follows: analysis, synthesis, systematization, standardization, etc. The integral indicator of the dynamics of the economic potential of Ukrainian regions assessment in the context of sustainable development is substantiated; it includes environmental, investment, institutional, innovation, cluster, infrastructure, financial, export and human capital indices. As a result three groups of regions with different levels of economic potential dynamics have been identified and clustered: regions with a high level of economic potential dynamics; regions with a stable level of economic potential dynamics; regions with low or negative levels of economic potential dynamics. The obtained results ascertain that special attention should be paid to the environmental, investment, innovation and institutional components of the economic potential management.
\end{abstract}

\section{Keywords}

economic potential, development of territories, sustainable development, management, environmental component

\section{JEL Classification G18, O11}

\section{INTRODUCTION}

Nowadays the issues of the territories' economic potential management should be oriented towards the usage of modern methods and instruments, enhancement of the economic potential and sustainable development ensuring. Sustainable development should be understood as the balance of the economic, social and environmental components of the social development. The complexity of such task is manifested in an adequate assessment of economic potential, the need to find weaknesses in the development of economic potential, the identification and application of the influence instruments, as well as strategic planning, and monitoring the management efficiency. In emerging markets countries (with negative economic trends and the needs of some sectors of the economy reformation) it's crucial to achieve high economic potential, which also stimulates sustainable development, that is, balancing of socio-ecological and economic systems.

\section{LITERATURE REVIEW}

The question of the formation of economic potential in the context of sustainable development was investigated by Brundtland (1987), Solow (1993), Daly (1996), Von Wright (1997), Wood and Richardson (2006), Dernbach and Mintz (2011). 
After the adoption of the Sustainable Development Goals (SDGs) set by the United Nations General Assembly in 2015 for the year 2030, most nations of the world are geared toward achieving these goals, including for the development of the economic potential of the territories (United Nations, 2019).

The foundations of the concept of sustainable development are laid by many scientists, especially Brundtland, who in the report "Our common future" (1987) focuses on issues not only of advanced economic development, but also its relationship with social and environmental development. Under sustainable development, the researcher considers the balance of economic, social, and environmental development or progress that will not harm future generations (Brundtland, 1987).

Abbot (1997) focuses on the economic component of sustainable development, and describes the concept as such, which promotes open economic relations and economic growth, since poverty is the main cause of environmental degradation, and economic growth provides its large resources and protection. At the same time, the basic notion is that economic growth must be sustainable in favor of future generations (Abbot, 1997).

Other scientists, for example, Solow (1993) adhere to the same position, the scientist considers sustainable development as an opportunity to support: 1) the economy, which will enable future generations to use the same resources that are used by the modern generation; 2) the natural environment in the same state in which we received it from our ancestors and should pass on to descendants; 3) the fair society, provided with all the necessary benefits (Solow, 1993).

Attention should also be paid to the approach of Sen (2003), which justifies the theory of the need to invest in self-development, respectively, innovative development of the state appears to be a stimulating factor in the search for balance and sustainability, as well as the achievement of the key purpose of sustainable development (Sen, 2003).

Dernbach and Mintz (2011) in the work "Environmental Laws and Sustainability", analyzing the issues of sustainable development in relation to environmental laws, emphasize the relevance of scientific research in the development of integrated decision-making systems and the use of valid laws aimed at maintaining the sustainability, both at the state level and at the level of the territories.

Porter and Van der Linde (1995) emphasize that the causes of negative environmental impact, which adversely affect sustainable development, are insufficient economic potential, low level of development, and introduction of innovations into production. Therefore, the main goal of sustainable development is the introduction of innovative technologies into production (Porter \& Van der Linde, 1995).

Daly (1996) notes that sustainable economic growth is essential for economic growth in the context of sustainable development. Among the key areas of such growth, the author distinguishes the gross domestic product, utility, competitiveness, natural resources, and production resources. Also, the researcher interprets the term "sustainable development" as a harmonious, balanced, non-conflict progress of all earthly civilization, groups of states (regions). That is, it refers to sustainable development from the point of view of achieving the equilibrium not only between constituents but also between separate territories (Daly, 1996).

Renda (2017) emphasizes in his research paper "How can Sustainable Development Goals be "mainstreamed in the EU's Better Regulation Agenda" the decisive role of developing a system of public administration in sustainable development in the state. Analyzing the successes of the EU states in the field of sustainable development, the author substantiates the thesis that the global goals defined by the UN should be integrated into the structure of state instruments for managing change in the state, in particular in reforms, strategies, programs, etc. Renda (2017) points to the positive changes that have taken place in most EU states based on the implementation of the decentralization of power reform (which is relevant for Ukraine), therefore, in his opinion, the purposes of sustainable development need to be implemented, starting with local self-government.

The concept of sustainable development requires changing the approaches and reforming the man- 
agement of the economic potential of the territories, while environmental responsibility is essential to achieve CSF (Makarenko et al., 2018).

Most scientists who studied the economic potential of the territories also focused on sustainable development.

Jovovic, Draskovic, Delibasic, and Jovovic (2017) argue that achieving the sustainable development at the regional level depends on the socio-economic situation in the region, governance processes and political situation in the region, the effectiveness of regional governance. According to them, the development of regions and territories today is complicated by negative financial and economic situation, food insecurity, and they argue that in order to achieve the goals of sustainable development, these ideas must be implemented first in the regions (Jovovic et al., 2017).

In particular, in the opinion of Makarenko (2012), the economic potential is the aggregate ability of the economy and its industries, enterprises, farms to carry out the production and economic activities, to produce the products, goods, and services, to meet the needs of the population, social needs, to ensure the development of production and consumer needs. The importance of taking into account the environmental and economic security in the management of the economic potential of the region is indicated in the work of Gryshchenko et al. (2012), which ensures the competitiveness of territories and rational use of resources.

The slowdown in economic development has led to the fact that the governments of many countries focus on the achievement of Sustainable Development Goals (Mishchenko et al., 2019). Consequently, the implementation of agricultural production, which corresponds to the principles of sustainable development, led to a separate direction - organic farming (Dobrovolska \& Espejo, 2018). Accordingly, the regions where organic farming is growing and occupies a significant share of crop production are characterized by higher level of competitiveness and innovation, while taking into account the environmental component of the development of economic potential.
The economic potential of the territories depends on the problems in the regional labor market. Therefore, a special role in management is played by the development of the potential of the labor force and various sectors of the economy, which are the components of the sustainable development of the country (Smachylo et al., 2018). Therefore, for the development of the economic potential of the territories, it is important to take into account the peculiarities of the regional labor market.

The achievement of sustainable development of the economy depends on the financial component of the economic potential of the territories, which requires the authorities to use the progressive forms, methods, and principles of cost management for the implementation of the regional financing (Kuzheliev et al., 2018). This is also confirmed in a study of Haber et al. (2018). The authors consider the financial component of economic security as the main element of sustainable financial development of the country.

Management of the export component of the economic potential on the basis of innovativeness in the sphere of trade also plays an important role in ensuring the sustainable development, in particular, helps to overcome the negative impact on the environment (Chowdhury \& Islam, 2018). Globalization and intensification of economic activity of regional subjects, and trade may have a negative impact on the ecology of territories.

As part of the study, the economic potential of the territories is a set of resources of the territories that can ensure the achievement of sustainable development goals and the opportunity to expand and improve the management activities in the regions.

Accordingly, the study will focus on economic potential. According to SDG 8 "Decent work and economic growth", sustainable economic growth, productivity growth, promotion of innovative solutions and small business development are foreseen. Also, within the framework of the purpose, the need for equalization of the economic development of the state territories is foreseen. All these parameters can be included in the evaluation of the economic potential of the territory.

According to the Sustainable Development Goals (SDGs) and SDG 8 (Ministry of Economic 
Development and Trade, 2017) "Decent work and economic growth," sixteen indicators of economic development were identified, and target values until 2030 were defined. The main objectives within the object of the study and the components can be considered as follows: the sustainability of production through modernization and innovation; the growth of export potential and added value of Ukrainian products; the development of high-tech production with sustainable development, that is, taking into account the environmental component of the development of territories; the growth of employment; reducing youth unemployment and ensuring the growth of youth participation in educational programs; the development of creative economy, institutions and the creation of financial opportunities for the realization of the potential of the population.

Therefore, in accordance with the SDG 8, the main components of the economic potential of the Ukrainian territories can be identified as follows: innovation; export; labor; environmental; human; institutional; financial. Consequently, the management of the economic potential of the territories in the conditions of sustainable development involves the use of a set of methods, measures and tools that will effectively affect the innovative, export, production, environmental, human, institutional and financial components of the potential of the regions to achieve the Sustainable Development Goals.

\section{RESEARCH OBJECTIVE}

The purpose of the study is: to develop a system (to propose an integral indicator for evaluating the economic potential of the territories), to evaluate the economic potential of the territories in terms of sustainable development and to identify the main components of the management of the economic potential of the territories. The base of the research is the regions of Ukraine.

\section{METHODS}

The study uses methods of analysis, synthesis to systematize the theoretical basis of the study of the importance of economic potential management in the context of its main components. The method of estimation of the economic potential of the territories on the basis of an integral indicator was offered. Normalized values of indicators of economic potential on the basis of deviations $\left(x_{i j}-a\right)$ and standardization of indicators by the scale of variation on the basis of minimum and maximum values of indicators were used for its determination. To study the economic potential in the context of sustainable development, the following information is used: The Sustainable Development Agenda 2030, Sustainable Development Goals: Ukraine 2017, the data of the World Bank and the State Statistics Service of Ukraine for the period 2007-2017 and the Global Innovation Index for 2018.

To normalize the indicators of development of the Ukrainian territories, the indicators of development of production, investment, the export-innovative potential of the regions in 2017 were used. This is due to the availability of data for this time period for all the territories.

\section{RESULTS}

According to the CSR 8, key indicators according to the World Bank and the State Statistics Service of Ukraine were selected for the analysis, characterizing the economic potential of the Ukrainian territories for 2007-2017: the index of physical volume of gross regional product, unemployment, export of high technologies, in particular in the context of selected for analysis regions of economic areas, the added value of industries, including the added value of agriculture, forestry and fisheries, gross capital formation (including in the context of the territories), annual growth of fixed assets, unemployment of the population aged 15-24, annual growth of gross value added, the rate of return of fixed assets (depreciation, \%), the material intensity of GDP, the share of gross fixed capital formation in GDP, the share of exports of goods using high and medium-high technology in the production of total exports of goods. Certain indicators make it possible to characterize such components of economic potential as production, export, innovation, and human capital (see Tables $1,2)$. 
Table 1. Dynamics of indices of physical volume of gross regional product (in the prices of the previous year, percentage)

Source: State Statistics Service of Ukraine.

\begin{tabular}{|c|c|c|c|c|c|c|}
\hline Region & 2007 & 2014 & 2015 & 2016 & 2017 & $\begin{array}{c}\text { Average, } \\
\text { 2007-2017 }\end{array}$ \\
\hline Ukraine & 107.9 & 93.4 & 90.2 & 102.4 & 102.5 & 99.4 \\
\hline Vinnytsia region & 103.4 & 104.6 & 97.1 & 106.5 & 101.8 & 103.6 \\
\hline Volyn region & 112.1 & 101.1 & 95.3 & 108.2 & 105.3 & 103.6 \\
\hline Dnipropetrovsk region & 105.3 & 95.1 & 90.3 & 98.4 & 102.1 & 100.3 \\
\hline Donetsk region & 104.6 & 67.1 & 61.3 & 99.1 & 95.2 & 95.5 \\
\hline Zhytomyr region & 105.1 & 103.6 & 98.1 & 105.2 & 105.0 & 104.1 \\
\hline Transcarpathian region & 108.2 & 102.8 & 93.5 & 97.3 & 103.1 & 101.3 \\
\hline Zaporizhzhia region & 108.5 & 100.4 & 94.7 & 99.7 & 103.1 & 101.2 \\
\hline Ivano-Frankivsk region & 100.8 & 97.6 & 92.0 & 99.0 & 107.1 & 100.5 \\
\hline Kyiv region & 105.9 & 99.4 & 94.0 & 105.7 & 104.6 & 102.9 \\
\hline Kirovohrad region & 97.9 & 100.6 & 91.7 & 105.0 & 98.6 & 103.2 \\
\hline Luhansk region & 105.2 & 61.0 & 47.7 & 118.0 & 83.8 & 94.1 \\
\hline Lviv region & 105.8 & 100.9 & 95.2 & 99.3 & 103.8 & 101.2 \\
\hline Mykolaiv region & 99.5 & 98.4 & 95.3 & 105.6 & 99.1 & 102.1 \\
\hline Odesa region & 106.3 & 98.3 & 95.8 & 104.2 & 104.2 & 101.8 \\
\hline Poltava region & 105.8 & 96.0 & 93.8 & 97.9 & 97.2 & 100.0 \\
\hline Rivne region & 104.5 & 102.6 & 93.4 & 100.3 & 103.5 & 101.7 \\
\hline Sumy region & 103.4 & 100.4 & 96.7 & 96.6 & 100.2 & 101.0 \\
\hline Ternopil region & 108.3 & 108.0 & 93.7 & 98.5 & 105.6 & 103.6 \\
\hline Kharkiv region & 107.2 & 97.9 & 90.9 & 102.1 & 101.4 & 101.1 \\
\hline Kherson region & 100.4 & 99.7 & 98.7 & 102.8 & 100.8 & 101.9 \\
\hline Khmelnytskyi region & 104.0 & 102.3 & 92.2 & 104.7 & 106.4 & 102.5 \\
\hline Cherkasy region & 106.5 & 98.9 & 95.0 & 101.8 & 98.3 & 103.2 \\
\hline Chernivtsi region & 108.3 & 98.3 & 94.7 & 99.4 & 103.5 & 101.9 \\
\hline Chernihiv region & 106.5 & 100.5 & 93.4 & 100.6 & 102.2 & 101.2 \\
\hline City of Kyiv & 119.7 & 96.1 & 93.3 & 105.5 & 105.7 & 103.6 \\
\hline
\end{tabular}

Table 2. Dynamics of indicators characterizing the economic potential of the territories of Ukraine in 2007-2017

\begin{tabular}{|c|c|c|c|c|c|c|}
\hline Indicator & 2007 & 2014 & 2015 & 2016 & 2017 & $\begin{array}{c}\text { Average } \\
2007-2017\end{array}$ \\
\hline $\begin{array}{l}\text { Unemployment, total (\% of total labor } \\
\text { force) (modeled ILO estimate) }\end{array}$ & 6.35 & 9.27 & 9.14 & 9.35 & 9.51 & 8.13 \\
\hline $\begin{array}{l}\text { High-technology exports (\% of } \\
\text { manufactured exports) }\end{array}$ & 3.65 & 6.51 & 7.27 & 5.75 & 4.98 & 5.27 \\
\hline $\begin{array}{l}\text { Industry (including construction), value- } \\
\text { added (\% of GDP) }\end{array}$ & 32.38 & 22.82 & 21.73 & 23.18 & 23.99 & 25.22 \\
\hline Manufacturing, value added (\% of GDP) & 17.64 & 12.23 & 11.90 & 12.22 & 12.39 & 13.12 \\
\hline $\begin{array}{l}\text { Industry (including construction), value- } \\
\text { added per worker (constant } 2010 \text { US\$) }\end{array}$ & 7957.43 & 5859.80 & 5265.15 & 5499.65 & 5731.22 & 6536.05 \\
\hline $\begin{array}{l}\text { Agriculture, forestry, and fishing, value- } \\
\text { added per worker (constant } 2010 \text { US\$) }\end{array}$ & 2135.16 & 4782.54 & 4421.38 & 4654.29 & 4646.07 & 3400.23 \\
\hline Gross capital formation (\% of GDP) & 32.83 & 13.40 & 15.93 & 21.72 & 20.75 & 21.86 \\
\hline Changes in inventories, annual growth \% & 62.78 & -134.35 & -312.81 & 168.95 & -8.64 & -18.55 \\
\hline Gross fixed capital formation (\% of GDP) & 26.12 & 14.14 & 13.55 & 15.46 & 16.00 & 18.02 \\
\hline $\begin{array}{l}\text { Unemployment, youth total (\% of total } \\
\text { labor force aged 15-24) (modeled ILO } \\
\text { estimate) }\end{array}$ & 13.10 & 23.26 & 22.52 & 23.14 & 18.99 & 18.33 \\
\hline $\begin{array}{l}\text { Gross value added at basic prices (GVA), } \\
\text { annual growth, \% }\end{array}$ & 33.87 & -27.58 & -33.52 & 2.39 & 19.66 & 3.00 \\
\hline
\end{tabular}


Data on physical volume indices of the gross regional product by regions of Ukraine (Table 1) confirm the slow economic growth, not exceeding $4 \%$, and the use of the economic potential of the territories is not in full. The negative dynamics of growth in the Donetsk and Luhansk regions is explained by the occupation of Ukrainian territories and hostilities. The same factors also adversely affect the development of the economic potential of other Ukrainian territories.

The data indicate the need to address the problems that hinder the development of economic potential, in particular, the reduction of unemployment, increasing the export potential of high technologies (management of export and innovation component of economic potential), ensuring the growth of the added value of industry and production (development of the production component of export potential), growth of investment in capital and fixed assets (development of the investment component), overcoming the problem of youth unemployment (development of human capital and intellectual capital) (Figure 1).

The economic potential of the Ukrainian territories depends on the available labor, material and financial resources. Consequently, the production component of the potential (Table 3) varies from area to area and site facilities to a particular economic region. In areas where high-tech industries are developed (Volyn, Kirovohrad, Kyiv with a high share of exports of machinery and equipment), production (Table 3) and the export potential is realized to a greater extent, but the environmental component of the development of territories requires the consideration in terms of sustainable development.

To ensure the development of the production component, there is a need to update fixed assets, which will contribute to the modernization of production, and therefore the implementation of the innovative component. The interconnection of the components of economic potential makes it necessary to use an integrated approach to its management.

The material intensity of GDP as a whole in Ukraine in 2017 amounted to 2.33. The material intensity of GDP is calculated as the ratio of the volume of intermediate expenditures from the tables "expenditure-output" of activities producing material products to the total GDP in Ukraine. The return on property, plant and equipment ratio was 55.1 in 2017. These indicators point to the significant production potential of the territories, which, with the modernization of technology, re-

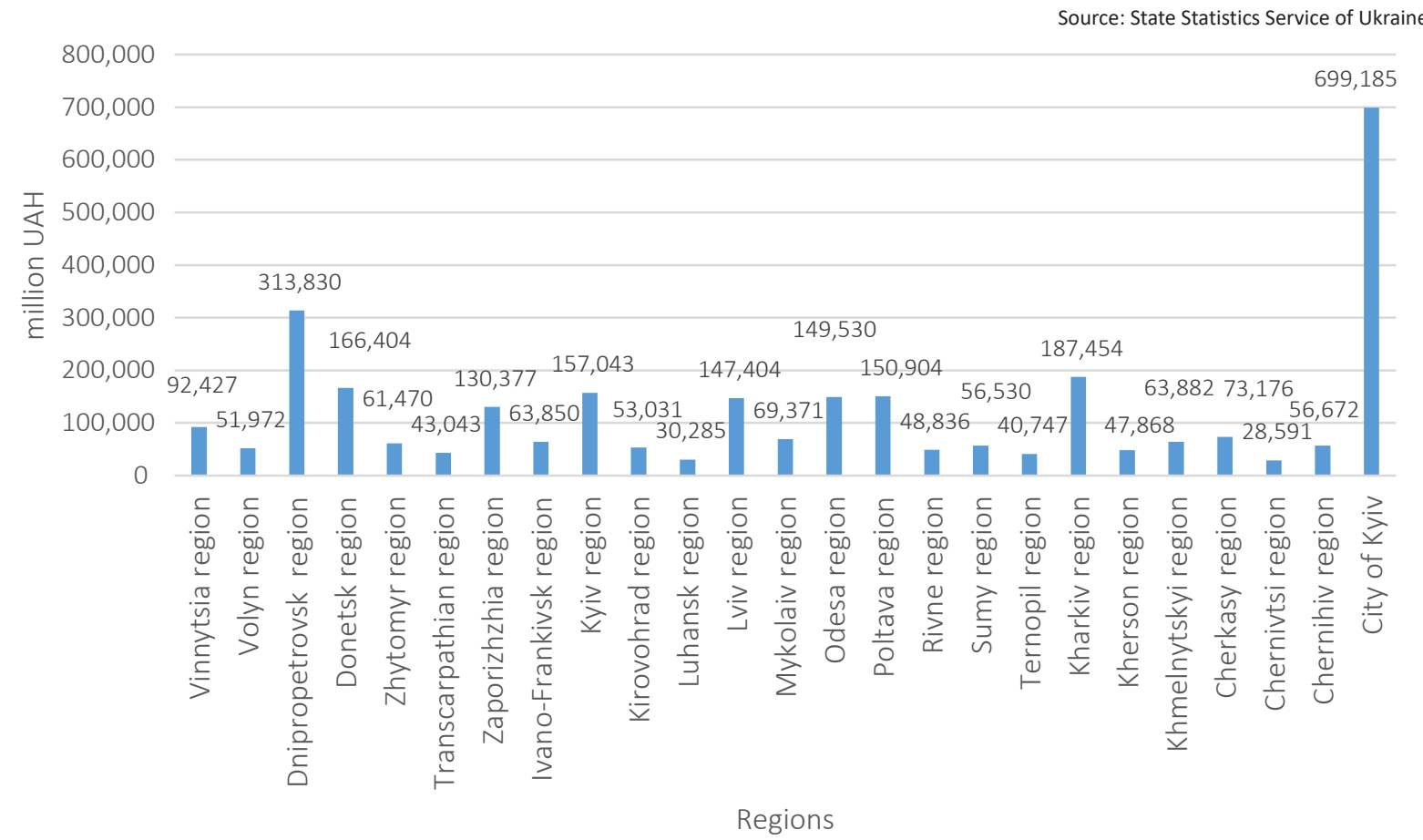

Figure 1. Gross regional product by regions of Ukraine in 2017, in actual prices, million UAH 
Table 3. Indicators of assessment of the production component of the economic potential of the Ukrainian territories by branches of material production in 2017 , mln UAH

Source: State Statistics Service of Ukraine.

\begin{tabular}{|c|c|c|c|c|c|c|}
\hline Region & $\begin{array}{l}\text { Agriculture, } \\
\text { forestry and } \\
\text { fisheries }\end{array}$ & $\begin{array}{l}\text { Processing } \\
\text { industry }\end{array}$ & $\begin{array}{l}\text { Mining and } \\
\text { quarrying }\end{array}$ & Construction & $\begin{array}{c}\text { Supply of electricity, } \\
\text { gas, steam and air } \\
\text { conditioning }\end{array}$ & $\begin{array}{c}\text { Issue (in actual } \\
\text { prices, million } \\
\text { UAH) }\end{array}$ \\
\hline Ukraine & 727,352 & $1,805,097$ & 344,157 & 326,496 & 283,985 & $6,255,397$ \\
\hline Vinnytsia region & 59,186 & 63,594 & 1,571 & 7,018 & 9,276 & 204,097 \\
\hline Volyn region & 19,484 & 25,961 & 159 & 4,922 & 1,821 & 102,800 \\
\hline Dnipropetrovsk region & 42,936 & 299,566 & 119,709 & 20,633 & 20,356 & 699,866 \\
\hline Donetsk region & 21,582 & 194,932 & 47,719 & 11,060 & 22,347 & 392,965 \\
\hline Zhytomyr region & 29,583 & 33,747 & 4,845 & 3,764 & 2,428 & 124,008 \\
\hline Transcarpathian region & 11,409 & 17,916 & 583 & 4,855 & 3,390 & 81,233 \\
\hline Zaporizhzhia region & 28,604 & 159,479 & 5,006 & 5,229 & 28,888 & 304,010 \\
\hline Ivano-Frankivsk region & 17,354 & 32,616 & 7,502 & 9,962 & 13,933 & 130,124 \\
\hline Kyiv region & 43,111 & 112,017 & 816 & 27,367 & 12,100 & 337,610 \\
\hline Kirovohrad region & 31,987 & 22,483 & 5,926 & 2,775 & 2,510 & 102,979 \\
\hline Luhansk region & 13,414 & 15,148 & 2,324 & 1,067 & 7,569 & 62,525 \\
\hline Lviv region & 27,297 & 67,007 & 16,497 & 16,839 & 12,754 & 285,858 \\
\hline Mykolaiv region & 26,646 & 40,683 & 869 & 4,997 & 11,173 & 141,640 \\
\hline Odesa region & 36,443 & 62,278 & 69 & 31,650 & 7,713 & 306,463 \\
\hline Poltava region & 41,501 & 96,609 & 79,471 & 7,877 & 5,703 & 297,719 \\
\hline Rivne region & 20,186 & 23,867 & 1,337 & 4,472 & 12,668 & 100,172 \\
\hline Sumy region & 31,626 & 30,792 & 3,719 & 2,538 & 2,647 & 112,207 \\
\hline Ternopil region & 26,805 & 17,430 & 817 & 2,892 & 1,492 & 82,575 \\
\hline Kharkiv region & 40,800 & 112,295 & 40,252 & 19,128 & 17,065 & 386,102 \\
\hline Kherson region & 31,379 & 23,561 & 144 & 2,188 & 3,151 & 96,801 \\
\hline Khmelnytskyi region & 41,221 & 33,345 & 843 & 5,035 & 7,223 & 133,400 \\
\hline Cherkasy region & 38,721 & 54,493 & 607 & 3,676 & 8,518 & 159,808 \\
\hline Chernivtsi region & 12,764 & 7,624 & 186 & 3,890 & 2,774 & 55,542 \\
\hline Chernihiv region & 33,139 & 28,408 & 3,175 & 2,435 & 5,036 & 113,681 \\
\hline City of Kyiv & 174 & 229,246 & 11 & 120,227 & 61,450 & $1,441,212$ \\
\hline
\end{tabular}

search and development, will be able to ensure the economic growth.

All areas have significant investment potential (Table 4), the development of which is constrained by innovative and institutional factors. Human capital also has significant development potential. This is evidenced by the unemployment rate of the population aged 20-64, which in 2017 amounted to 18.3\%.

The share of gross fixed capital formation in GDP - the ratio of capital investments to GDP, \% (State Statistics Service of Ukraine). In general, for Ukraine, it is advisable to calculate the indicator on the basis of the "input-output" table as the ratio of gross fixed capital formation and GDP for a certain period. Consequently, in 2017, the share of gross fixed capital formation in GDP was 15.03\%.

On average, the export component of the economic potential of the territories amounted to $22.7 \%$ in
2017. This means that Ukrainian enterprises can enter new markets and increase the volume of exports of goods using high- and medium-high-level technologies in production. These products include products of chemical and related industries, engineering, electrical equipment, optical devices, aircraft. Export potential depends on the innovation potential. Increasing the level of innovation use and financing will ensure that the economic potential of the territories is used to the full extent. In 2018, Ukraine ranked 43rd in the Global Innovation Index (2019) (Figure 2).

Environmental, investment and institutional components of the economic potential of the Ukrainian territories require priority measures to ensure the regional development.

Assessing the indicators of development of economic potential of territories requires the use of a synergetic approach because all components are interrelated. 
Table 4. Indicators of evaluation of investment and innovation component of the economic potential of the Ukrainian territories in 2017

Source: State Statistics Service of Ukraine.

\begin{tabular}{|c|c|c|c|c|c|}
\hline \multirow[b]{2}{*}{ Region } & \multirow{2}{*}{$\begin{array}{l}\text { Gross regional product (in } \\
\text { actual prices, million UAH) }\end{array}$} & \multicolumn{3}{|c|}{ Developed (used) capital investment } & \multirow{2}{*}{$\begin{array}{l}\text { Share of gross fixed capital } \\
\text { formation in GDP, \% } 2017\end{array}$} \\
\hline & & UAH, mln & $\begin{array}{l}\% \text { of total } \\
\text { volume }\end{array}$ & $\begin{array}{c}\text { per person, } \\
\text { UAH }\end{array}$ & \\
\hline Ukraine & 2983882 & 448461.5 & 100,0 & 10598.0 & $15.03 \%$ \\
\hline Vinnytsia region & 92427 & 11744.1 & 2.6 & 7451.8 & $12.71 \%$ \\
\hline Volyn region & 51972 & 7041.9 & 1.6 & 6790.8 & $13.55 \%$ \\
\hline Dnipropetrovsk region & 313830 & 42908.5 & 9.6 & 13294.8 & $13.67 \%$ \\
\hline Donetsk region & 166404 & 17268.9 & 3.9 & 4102.5 & $10.38 \%$ \\
\hline Zhytomyr region & 61470 & 7722.0 & 1.7 & 6244.4 & $12.56 \%$ \\
\hline Transcarpathian region & 43043 & 5623.7 & 1.3 & 4478.7 & $13.07 \%$ \\
\hline Zaporizhzhia region & 130377 & 15879.7 & 3.5 & 9176.2 & $12.18 \%$ \\
\hline Ivano-Frankivsk region & 63850 & 9707.8 & 2.2 & 7055.2 & $15.20 \%$ \\
\hline Kyiv region & 157043 & 34494.5 & 7.7 & 19840.4 & $21.97 \%$ \\
\hline Kirovohrad region & 53031 & 7320.9 & 1.6 & 7669.2 & $13.80 \%$ \\
\hline Luhansk region & 30285 & 3329.8 & 0.7 & 1529.6 & $10.99 \%$ \\
\hline Lviv region & 147404 & 24105.9 & 5.4 & 9590.8 & $16.35 \%$ \\
\hline Mykolaiv region & 69371 & 11178.0 & 2.5 & 9762.3 & $16.11 \%$ \\
\hline Odesa region & 149530 & 22299.7 & 5.0 & 9394.4 & $14.91 \%$ \\
\hline Poltava region & 150904 & 15855.6 & 3.5 & 11225.3 & $10.51 \%$ \\
\hline Rivne region & 48836 & 6126.9 & 1.4 & 5278.8 & $12.55 \%$ \\
\hline Sumy region & 56530 & 6947.1 & 1.6 & 6331.6 & $12.29 \%$ \\
\hline Ternopil region & 40747 & 7150.6 & 1.6 & 6793.9 & $17.55 \%$ \\
\hline Kharkiv region & 187454 & 19361.7 & 4.3 & 7219.2 & $10.33 \%$ \\
\hline Kherson region & 47868 & 7362.2 & 1.6 & 7012.4 & $15.38 \%$ \\
\hline Khmelnytskyi region & 63882 & 10499.9 & 2.3 & 8224.4 & $16.44 \%$ \\
\hline Cherkasy region & 73176 & 8144.2 & 1.8 & 6663.8 & $11.13 \%$ \\
\hline Chernivtsi region & 28591 & 2992.1 & 0.7 & 3308.6 & $10.47 \%$ \\
\hline Chernihiv region & 56672 & 7351.1 & 1.6 & 7219.7 & $12.97 \%$ \\
\hline City of Kyiv & 699185 & 136044.8 & 30.3 & 47093.3 & $19.46 \%$ \\
\hline
\end{tabular}

Source: State Statistics Service of Ukraine.

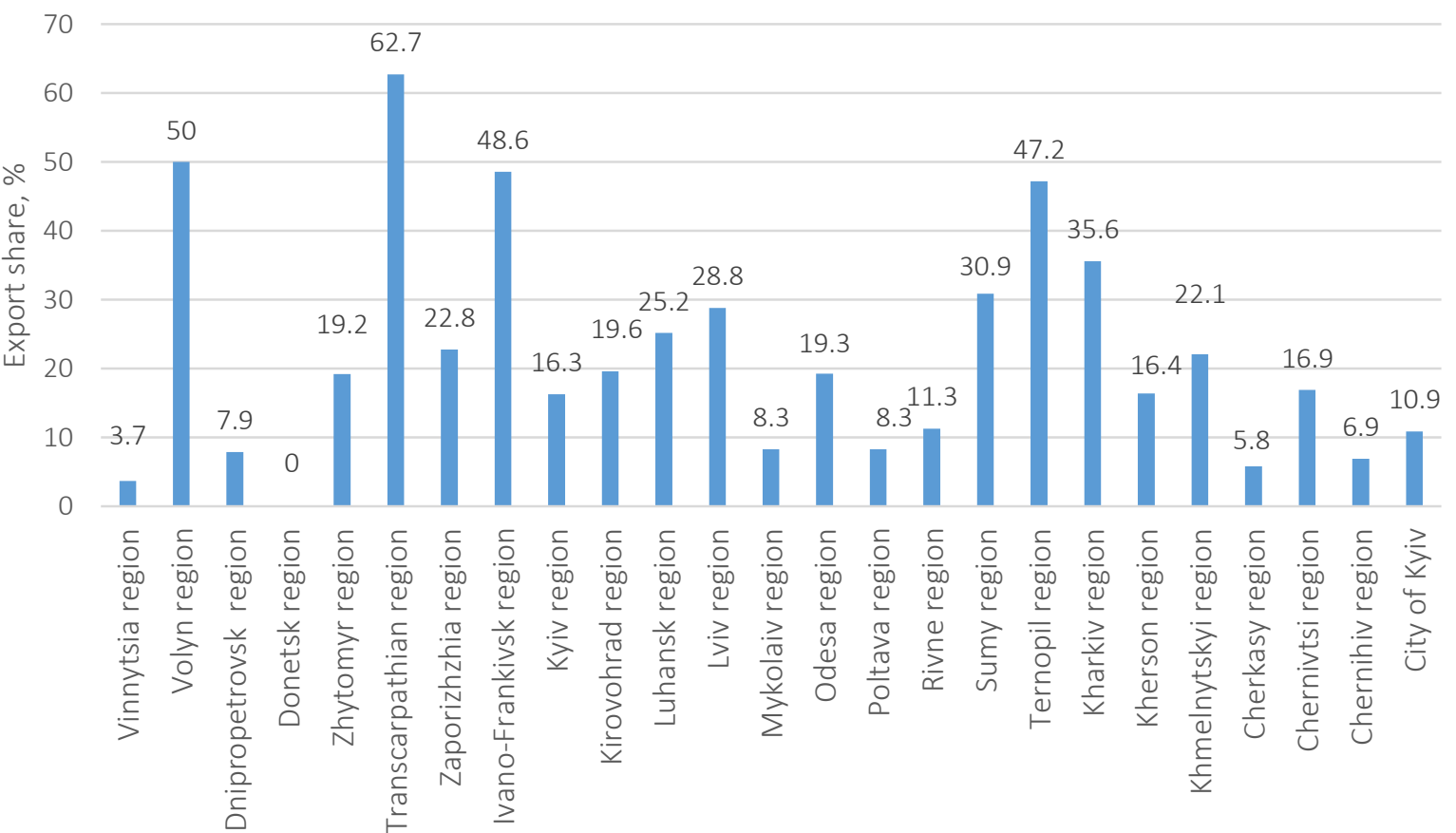

Regions

Figure 2. Indicators of assessment of the export and innovation component of the economic potential of the territories of Ukraine in 2017 (the share of exports of goods using high- and mediumhigh-level technologies in the production of total exports of goods, \%) 
The analysis of indicators of economic potential of the Ukrainian territories allows us to offer an integral indicator of assessing the level of public administration in the context of components. To determine the integral indicator, we apply normalized values of economic potential indicators based on deviations proposed in the work by Voloshchuk (2009). According to a separate formula, the normalization is delayed for indicators of economic potential characterizing its development; that is, the growth of the indicator indicates positive trends and negative trends (Voloshchuk, 2009).

At the same time, an integral indicator is an indicator that is calculated as a result of weighing a certain combination of indicators and comprehensively characterizes the economic potential and the state of economic potential management. The integral indicator includes all certain components identified in the analysis of economic potential on the basis of indicators of sustainable development:

$$
\begin{aligned}
& I_{s d}=\frac{I_{e}+I_{i n v}+I_{i n s}+I_{i n n}+I_{c l}+I_{i n f}+I_{f}+I_{e x p}+I_{h}}{n}= \\
& =\frac{\sum_{i=1}^{n} I_{j=1}^{k}}{n} .
\end{aligned}
$$

where $I_{s d}$ - integral indicator of economic potential of territories, $I_{i j}$ - the normalized $i$-th indicator of the $j$-th aggregate, $I_{e}$ - normalized indicators of the environmental component of the economic potential, $I_{i n v}$ - normalized indicators of the institutional component of the economic potential, $I_{i n s}$ - normalized indicators of the innovation component of the economic potential, $I_{i n n}$ - normalized indicators of the innovation component of the economic potential, $I_{c l}$ - normalized indicators cluster component of the economic potential, $I_{i n f}$ - normalized indicators of infrastructure component of the economic potential, $I_{f}-$ normalized indicators of the financial component of the economic potential, $I_{\text {exp }}$ - normalized indicators of the export component of the economic potential, $I_{h}$ - normalized indicators of human capital and human resources.

The most problematic indicators of sustainable development should be given the greatest weight, which in the future makes it possible to determine the territories and regions that are characterized by the lowest level of economic development. The higher value of the index will characterize the high level of development of the economic potential of the territory.

To implement the normalization of indicators of development of the Ukrainian territories, we use three key indicators that characterize such components:

- production component - indices of physical volume of gross regional product in 2017 (in the prices of the previous year, percent);

investment component - share of gross fixed capital formation in GDP in 2017, \%;

- export-innovation component - the share of exports of goods using high- and medium-high-level technologies in the total volume of exports of goods in 2017, \%.

These components, and in particular the investment component, have an impact on several key factors: efficiency of public administration, creation of fiscal and tax conditions for the development of economy and investment, low risk of investment, and others.

The choice of data and time period for calculations is related to the availability of information in the context of regions.

The first iteration involves determining the minimum and maximum values of indicators in the context of each component. The second iteration involves the use of formula (1) to calculate the normalized values of the indicators of each component. The third iteration involves the use of formula (3) to rank the regions of Ukraine by the level of economic potential of the territories. That is, normalized indicators are added and divided into the number of indicators of economic potential (in our case, there are 3). As a result of the calculation the ranking of regions according to the available economic potential was obtained (Figure 3). The ranking is based on the overall indicator of economic potential assessment. 


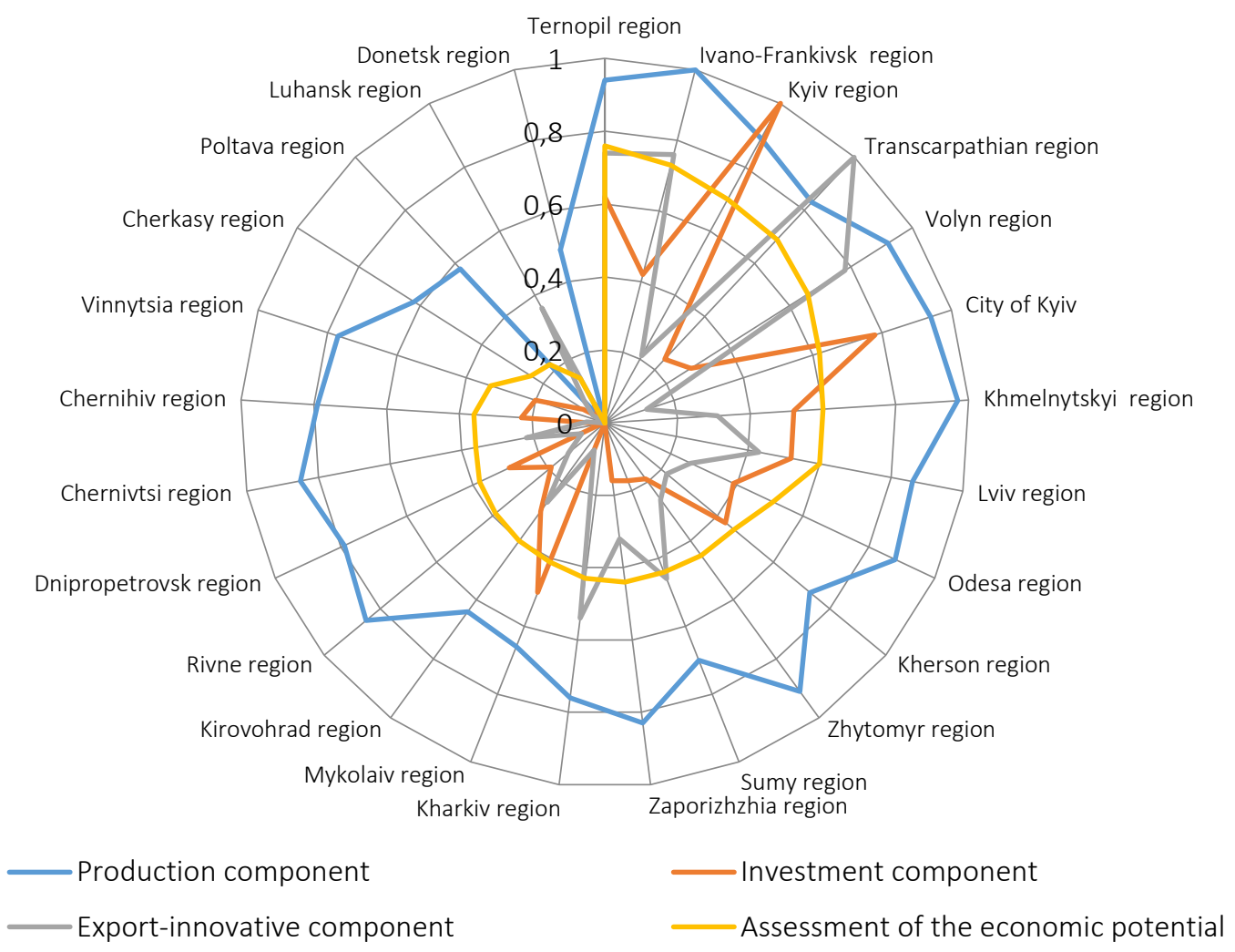

Figure 3. Ranking of Ukrainian regions by economic potential of territories in 2017

The normalized performance of each component reflects the strengths and weaknesses of each region. Consequently, Ternopil, Ivano-Frankivsk, Kyiv, Transcarpathian, Volyn, Khmelnitskyi, Lviv, Odesa, Zhytomyr regions have high production potential but are characterized by low or medium values of investment and export-innovative potential. Territories with a high level of investment potential (Kyiv region, Kyiv city, Ternopil region), at the same time, have medium or low export-innovation potential. The territories with a high level of export-innovative potential (Transcarpathian, Volyn, Ternopil, Ivano-Frankivsk), thanks to the development of high-tech industries and exports of engineering products, and electrical devices, were able to provide primacy in assessing the development of economic potential (Figure 4).

Thus, the calculations give grounds to assert the importance and priority of the development of the innovative component, which is the primary basis for the development of exports, production growth and investment in the development of territories.

\section{DISCUSSION}

Based on the results of the evaluations, there can be identified three groups of regions with different levels of economic potential dynamics that can be managed:

Group I. Regions with a high level of economic potential dynamics (Ternopil region, IvanoFrankivsk region, Kyiv region, Transcarpathian region, Volyn region, City of Kyiv, Khmelnytskyi region, Lviv region). For these regions, it is necessary to support potential growth rate.

Group II. Regions with a stable level of economic potential dynamics (Odesa region, Kherson region, Zhytomyr region, Sumy region, Zaporizhzhia region, Kharkiv region, Mykolaiv region, Kirovohrad region). For these regions, it is necessary to increase the pace of growth of the potential. It would be worthwhile for this group of regions to pay more attention to innovative development in all sectors of the economy, energy efficiency, clean environment, and energy-saving technologies. For these regions, it 


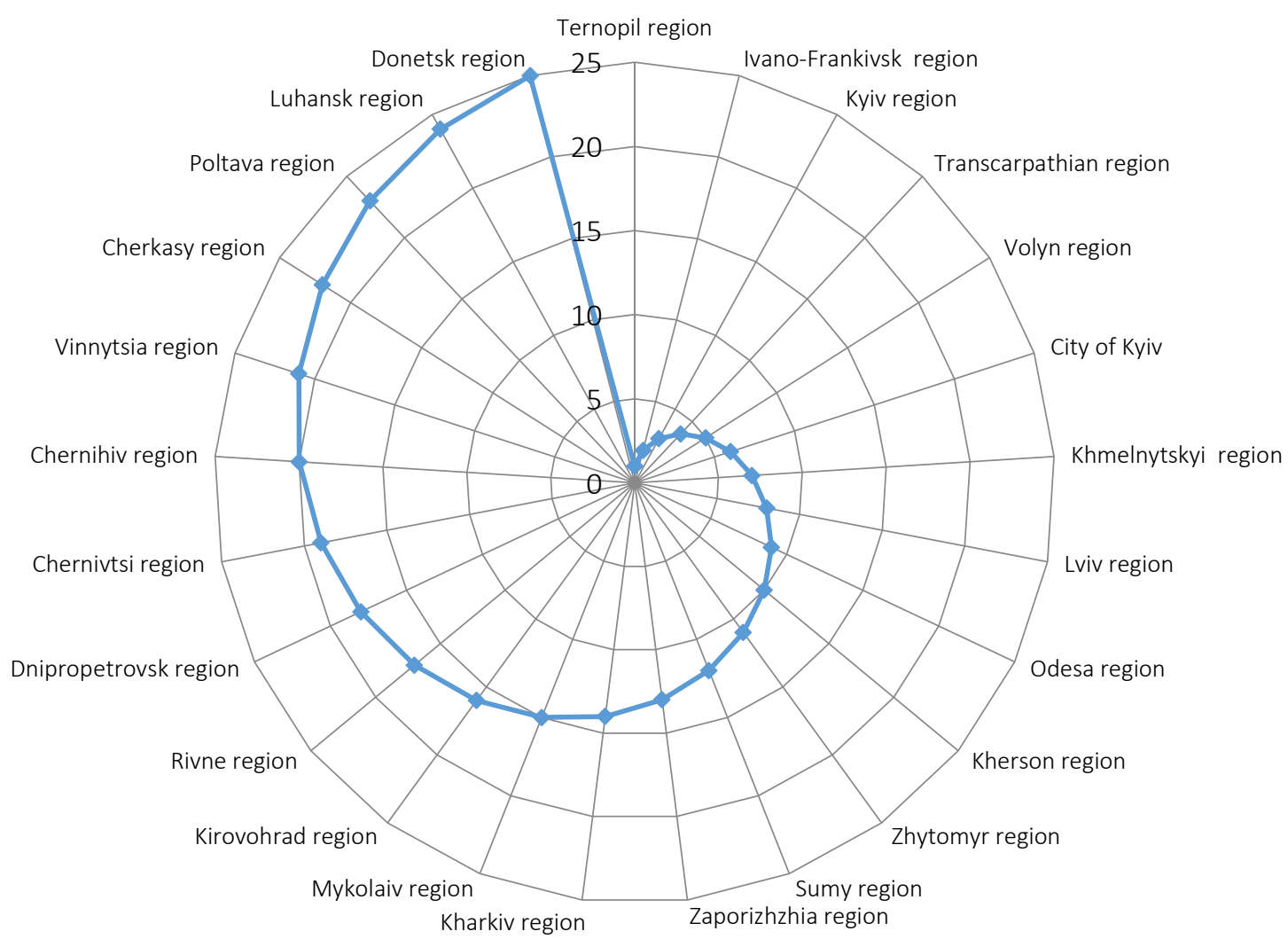

Figure 4. Ranking of the Ukrainian regions in 2017

is necessary to achieve the rapid growth of the export potential.

Group III. Regions with low or negative economic potential dynamics (Rivne region, Dnipropetrovsk region, Chernivtsi region, Chernihiv region, Vinnytsia region, Poltava region, Luhansk region, Donetsk region). For these regions, the priority is to ensure the growth of the gross regional product, reduce migration, and create the conditions for business development.

Having considered the geographical location regions of Ukraine and features of regional there are several categories of development regional interaction:

Group I. Interaction between adjacent regions with high economic potential, for example, Ternopil region, Ivano-Frankivsk region. In such regions, cooperation in innovation and technology, joint interregional projects, research, etc. are possible.

Group II. Interaction of regions with a stable level of economic potential dynamics and regions with low or negative economic potential dynamics, for example, Kirovohrad region, Poltava region. In such interaction, regions with low economic development should use the experience of management, business interaction, innovative technologies in more developed regions.

According to the results of the analysis, it can be seen that the investment component that needs the most intervention and activation is needed (the indicator of attraction of investments in the regions of Ukraine is low), the institutional component, the strengthening of the export potential for the change in the structure of external economic balance and the environmental development.

Particular attention should be paid to the innovative component of the development of the economic potential of the regions, since the introduction of innovations has a positive impact on the environmental development of the territory, to increasing the labor productivity and the quality of life of the population. The components of the Global Innovation Index 2019 indi- 
cate that special attention in the management of the economic potential of the territories should be paid to:

- training programs for personnel in enterprises, that is, the development of human capital and education during life (rating of the subindex for firms offering formal training is 68 with an estimate of 25.33);

- development of cooperation between higher educational institutions and enterprises of various sectors of the economy (rating of the university/industry research collaborationis 70 with an estimate of 39.84 );

- development of the cluster component of economic potential at the state and regional level (rating of the state of cluster development is 98 with an estimate of 35.53);

- development of joint entrepreneurship at the regional level to stimulate the investment component of the economic potential (rating of the joint venture/strategic alliance deals is 87 with an estimate of 4.69 );

development of public administration and administrative services (government effectiveness is 102 with an estimate of 30.70 );

- development of regulatory and institutional environment (regulatory environment is 78 with an estimate of 60.19);

- financing of research and development at the regional level (gross expenditure on R\&D (GERD) is 60 with an estimate of 11.07);

- financing the development of the information and communication sector at the regional level (ICT use of 94 with a rating of 31.70, ICT access with a rating of 66.00 );

- development of e-government (government's online service 70 with a rating of 58.70).

\section{CONCLUSION}

The study identifies the main components of the territories economic potential management, such as environmental, investment, institutional, innovation, cluster, infrastructure, financial, export and human capital development. According to the identified components, the integral indicator is proposed to assess the economic potential of the territories, which allows defining the priority areas of management.

In the context of sustainable development special attention should be paid to the environmental, investment and institutional components. These components are characterized by the lowest level of development, which does not provide rapid economic growth and slows down the pace of development of the regional economy. It's proved that the environmental component can contribute to the formation of new promising sectors of the economy that will ensure the competitiveness of the regions. The investment and innovation component of management will ensure the rapid transfer of financial resources and innovations to all sectors of the economy. The development of the infrastructure component of management will simplify the functioning of economic agents. The balance of management methods and levers, in general, will provide a synergetic effect of management of the economic potential of the territories. The problems of further research are the issues of society's readiness to implement eco-ideas and ideas of sustainable development in order to ensure sustainable development in the context of permanent changes and globalization processes.

\section{REFERENCES}

1. Abbot, K. (1996). Economic Issues and Political Participation: The Evolving Boundaries in International Federalism. Cardazo Law Review, 18, 971-982.
2. Brundtland, G. H. (1987). Selected speeches on the Commission and its report. Retrieved from https://idlbnc-idrc.dspacedirect.org/ handle/10625/20579
3. Chowdhury, T., \& Nazrul Islam, A. (2018). China's trade in climate smart goods: an analysis of trends and trading patterns. Environmental Economics, 9(3), 12-22. https://doi. org/10.21511/ee.09(3).2018.02 
4. Daly, H. (1996). Beyond Growth: The Economics of Sustainable Development. Boston: Beacon Press.

5. Dernbach, J., \& Mintz, A. (2011). Environmental laws and sustainability: an introduction. Sustainability, 3(3), 531-540. https://doi. org/10.3390/su3030531

6. Dobrovolska, O., \& Recio Espejo, J.-M. (2018). Institutional support for the organic farming development - a conceptual framework. Environmental Economics, 9(4), 50-59. https://doi.org/10.21511/ ee.09(4).2018.05

7. Global Innovation Index (2019). Explore economy reports from the GII 2019. Retrieved from https:// www.globalinnovationindex.org/ analysis-economy

8. Gryshchenko, V. F., Dreval, O. Yu., \& Gryshchenko, I. V. (2012). Проблеми управління економічним потенціалом регіону з урахуванням вимог еколого-економічної безпеки [Problemy upravlinnia ekonomichnym potentsialom rehionu z urakhuvanniam vymoh ekolohoekonomichnoi bezpeky]. Aktualni Problemy Ekonomiky, 7, 132-145.

9. Haber, J., Bukhtiarova, A., Chorna, S., Iastremska, O., \& Bolgar, T. (2018). Forecasting the level of financial security of the country (on the example of Ukraine). Investment Management and Financial Innovations, 15(3), 304-317. https://doi. org/10.21511/imfi.15(3).2018.25

10. Jovovic, R., Draskovic, M., Delibasic, M., \& Jovovic, M. (2017). The concept of sustainable regional development - institutional aspects, policies and prospects. Journal of International Studies, 10(1), 255266. https://doi.org/10.14254/20718330.2017/10-1/18

11. Kliuchnyk, A. V. (2011). Формування та розвиток економічного потенціалу сільських територій Украӥни [Formuvannia ta rozvytok ekonomichnoho potentsialu silskykh terytorii Ukrainy]. Mykolaiv: Dyzain ta polihrafiia.

12. Kuzheliev, M., Rekunenko, I., Nechyporenko, A., \& Nemsadze, G. (2018). Discretionary budget expenditure in the system of state regulation of the country's socioeconomic development. Public and Municipal Finance, 7, 8-18. https:// doi.org/10.21511/pmf.07(4).2018.02

13. Makarenko, I., Bychenko, D., Makarenko, S., \& Qasimova, G. (2018). Environmental responsibility mechanism development in the public sector of the economy. Environmental Economics, 9(3), 28-41. https://doi.org/10.21511/ ee.09(3).2018.04

14. Makarenko, M. (2012). Управління економічним потенціалом регіону як основою формування конкуретних переваг регіону [Upravlinnia ekonomichnym potentsialom rehionu yak osnovoiu formuvannia konkurentnykh perevah rehionu]. Aktualni problemy ekonomiky, 4(130), 217-224. Retrieved from http://www.irbis-nbuv. gov.ua/cgi-bin/irbis_nbuv/cgiirbis_64.exe?I21DBN=LINK\&P21D $\mathrm{BN}=\mathrm{UJRN} \& \mathrm{Z} 21 \mathrm{ID}=\& \mathrm{~S} 21 \mathrm{REF}=10$ $\& S 21 \mathrm{CNR}=20 \& S 21 \mathrm{STN}=1 \& S 21 \mathrm{~F}$ $\mathrm{MT}=\mathrm{ASP} \_$meta\&C21COM=S\&2 $\mathrm{S} 21 \mathrm{P} 03=\mathrm{FILA}=\& 2$

S21STR=ape_2012_4_24

15. Mishchenko, S., Naumenkova, S., Mishchenko, V., Ivanov, V., \& Lysenko, R. (2019). Growing discoordination between monetary and fiscal policies in Ukraine. Banks and Bank Systems, 14(2), 40-49. https:// doi.org/10.21511/bbs.14(2).2019.04

16. Mykhalchenko, H. (2018). The improvement of management of social and labor relations as one of the directions of economic development. Social and labor relations: theory and practice, $8(2)$, 56-68. https://doi. org/10.21511/slrtp.8(2).2018.06

17. Oxford Powerty \& Human Development Initiative (2019). Development as capability expansion. Retrieved from http://www.ophi.org.uk/wpcontent/uploads/Sen-2003_Development-as-Capability-Expansion. pdf

18. Porter, M. E., \& Van der Linde, C. (1995). Toward a new conception of the environment-competitiveness relationship. Journal of Economic Perspectives, 9(4), 97-118. Retrieved from https://www.jstor.org/ stable/2138392?seq=1\#page_scan_ tab_contents

19. Renda, A. (2017). How can Sustainable Development Goals be "mainstreamed" in the EU's
Better Regulation Agenda? CEPS Policy Insights: Policy Paper, 12, 1-17. Retrieved from https://www. ceps.eu/ceps-publications/how-cansustainable-development-goals-bemainstreamed-eus-better-regulation-agenda/

20. Sen, A. (1989). Development as capability expansion. Journal of Development Planning, 19, 41-58.

21. Smachylo, V., Kalinichenko, L., \& Arshava, E. (2018). Substantiating the factors of influence on the employment level in the transport industry of Ukraine. Social and labor relations: theory and practice, $8(2)$, 42-55. https://doi.org/10.21511/ slrtp.8(2).2018.05

22. Solow, R. (1993). Sustainability: An economist's perspective. In R. N. Stavins (Ed.), Economics of the Environment: selected readings (pp. 10011010). Retrieved from https:// deakin.rl.talis.com/items/4250BF67DA4D-8A9D-B205-BB8780E20673. html

23. State Statistics Service of Ukraine. (2019). Retrieved from http://www. ukrstat.gov.ua

24. United Nations (2019). About sustainable Development Goals. Retrieved from https://www.un.org/ sustainabledevelopment/sustainable-development-goals/

25. United Nations Ukraine (2017). Цілі сталого розвитку: Україна [Tsili staloho rozvytku: Ukraina]. Retrieved from http://www.un.org. ua/images/SDGs_NationalReportUA_Web_1.pdf

26. Voloshchuk, R. (2009). Підходи до нормування економічних показників [Pidkhody do normuvannia ekonomichnykh pokaznykiv]. Induktyvne modeliuvannia skladnykh system, 2, 17-25. Retrieved from http://dspace.nbuv. gov.ua/handle/123456789/16975

27. Wood, S., \& Richardson, B. (2006). Environmental law for sustainability. Oxford, UK: Hard publishing. Retrieved from https://papers.ssrn. com/sol3/papers.cfm?abstract $\mathrm{id}=881401$

28. Wright, V. (1997). Progress: Fact and fiction. In A. Burgen, P. McLaughhlin \& J. Mittelstrab (Eds.), The idea of progress (pp. 1-18). Berlin: Walter de Gruyter. 